\title{
Potensi Formulasi Sediaan Sabun Padat Minyak Kelapa dengan Pengisi Kaolin sebagai Media Pembersih Najis Mughallazah
}

\section{Potency of Coconut Oil Bar Soap Formulation with Kaolin Filler as NajisMughallazah Media Cleaning}

\author{
Vera Diana Panjaitan*, Lilis Sukeksi, Iriany, Siswarni \\ Departemen Teknik Kimia, Fakultas Teknik, Universitas Sumatera Utara Jalan \\ Almamater Kampus USU, Medan, 20155, Indonesia \\ *Email: Veradianapanjaitan@gmail.com
}

\begin{abstract}
Abstrak
Al- Qur'an menjelaskan najis mughallazah harus disucikan menggunakan air sebanyak 7 kali dan salah satunya menggunakan tanah. Penambahan tanah liat pada sabun membantu menghilangkan DNA najis yang melekat dipermukaan kulit. Penelitian ini diadakan untuk mengetahui pengaruh peningkatan jumlah kaolin dan suhu reaksi terhadap kadar air dan kekerasan sabun; mengetahui apakah formula sabun memenuhi syarat mutu SNI serta mengetahui apakah formula sabun mampu menghilangkan DNA derivat Babi menggunakan analisa metode PCR. Reaksi dirancang pada 4 suhu reaksi $\left(50^{\circ} \mathrm{C}\right.$ $80^{\circ} \mathrm{C}$ ), konsistensi kaolin $(10 \%-20 \%)$, konsentrasi $\mathrm{NaOH} 35 \%$, waktu reaksi 10 menit dan kecepatan pengadukan $250 \mathrm{rpm}$. Hasil penelitian menunjukkan semua variasi memenuhi standar SNI. Hasil terbaik didapat pada sabun $15 \% ; 50^{\circ} \mathrm{C}$ dan $17,5 \% ; 60^{\circ} \mathrm{C}$. Bilasan pertama sabun mampu menghilangkan DNA najis yang dioleskan ketangan manusia. Pencucian DNA menggunakan air dan Sabun konvensional menunjukkan sisa DNA pada elektroforesis PCR. Formulasi sabun padat kaolin yang dihasilkan dapat menghilangkan DNA serta memenuhi standart SNI 06-3532-2016.
\end{abstract}

Kata kunci: minyak kelapa, kaolin, najis mughallazah, sabun

\begin{abstract}
Qur'an explains najis mughallazah be purified using water as much as 7 times and one of which uses the ground. The addition of clay to the soap helps remove impure DNA attached to the surface of the skin. This study was conducted to determine the effect of an increase in the amount of kaolin and reaction temperature on water content and hardness of soap; determine whether the soap formulas meet the quality requirements of SNI and determine whether the soap formula capable of eliminating the derivatives pig DNA using PCR analysis method. The reaction was designed in 4 reaction temperatures $\left(50^{\circ} \mathrm{C}-80^{\circ} \mathrm{C}\right)$, the consistency of kaolin $(10 \%-20 \%), 35 \% \mathrm{NaOH}$ concentration, reaction time 10 minutes and the stirring speed of $250 \mathrm{rpm}$. The results showed that all variations meet SNI standards. The best results were obtained in $15 \% ; 50^{\circ} \mathrm{C}$ and $17.5 \% ; 60^{\circ} \mathrm{C}$. First, rinse the soap can eliminate DNA smeared unclean human hands. DNA washing using water and soap shows the remaining conventional PCR DNA electrophoresis. Kaolin solid soap formulation produced may eliminate DNA and meet the standard SNI 06-3532-2016.
\end{abstract}

Keywords: coconut Oil, kaolin, najis mughallazah, soap

\section{Pendahuluan}

Lembaga Pengkajian Pangan, Obat-obatan dan Kosmetika (LP POM) Majelis Ulama Indonesia adalah lembaga yang bertugas untuk meneliti, mengkaji, menganalisis, dan memutuskan produkproduk baik pangan dan turunannya, obat-obatan dan kosmetika apakah aman baik dari sisi kesehatan dan sisi agama Islam (yakni halal dan baik untuk dikonsumsi bagi umat Islam) khususnya di wilayah Indonesia, memberikan rekomendasi, merumuskan ketentuan dan bimbingan kepada masyarakat [1]. Kata halâl berasal dari bahasa Arab yang berarti "melepaskan" dan "tidak terikat", secara etimolgis halâl berarti hal-hal yang boleh dan dapat dilakukan karena bebas atau tidak terikat dengan ketentuanketentuan yang melarangnya [2]

Apabila sesuatu terkena najis ini, ia mestilah dibasuh sebanyak tujuh kali. Salah satu daripadanya ialah dengan air yang bercampur tanah[3].Salah satu jenis mineral yang memiliki sifat antimikroba dengan cara mengadsorbsi bakteri dan virus adalah kaolin. Kaolin dapat digunakan dalam desinfektan air karena kemampuannya dalam mengadsorbsi bakteri yang terdapat didalam air [4].

Seiring dengan perkembangan zaman dan teknologi, penghilangan najis dengan menggunakan debu/tanah dirasa kurang praktis dikehidupan modern, maka muncullah ide untuk mengkombinasikan tanah 
didalam sabun sebagai pembersih yang lebih praktis untuk kegunaan bersuci. Penambahan kaolin juga diharapkan dapat memperbaiki sifat dan karakteristik sabun yang dihasilkan.

Peneliti sebelumnya pernah melakukan penelitian tentang New Approach of Samak Clay Usage for Halal Industry Requirementmenunjukkan bahwa tanah liat samak untuk aplikasi pembersihan Islami dapat secara signifikan berkontribusi pada pertumbuhan industri halal secara keseluruhan dan meningkatkan tingkat kepercayaan konsumen terhadap produk halal[5].Adapun penelitian yang telah dilakukan dan menunjukkan kemampuan kaolin sebagai pengisi sabun padat berjudul Physical Properties of Kaolin Used In Soap Production In Nigeria yang menyimpulkan tekstur butiran halus dari kaolin membuatnya berguna sebagai pengisi dalam produksi sabun, kosmetik, dan juga industri farmasi [6].

Dengan adanya penelitian ini akan diketahui formula sabun padat berpengisi kaolin yang memenuhi syarat mutu SNI 06-3532-2016 dan faktorfaktor yang memengaruhi kualitas sabun padat yang meliputi suhu reaksi dan banyaknya konsistensi kaolin. Sabun padat yang dihasilkan akan diuji untuk mengetahui kemampuannya dalam menghilangkan DNA najis.

\section{Teori}

\section{Minyak Kelapa}

Minyak kelapa merupakan minyak yang diperoleh dari kopra (daging buah kelapa yang dikeringkan) atau dari perasan santannya. Kandungan minyak pada daging buah kelapa tua diperkirakan mencapai 30-35\%, atau kandungan minyak dalam kopra berkisar $63,72 \%$. Minyak kelapa sebagaimana minyak nabati lainnya merupakan senyawa trigliserida yang tersusun atas berbagai asam lemak dan $90 \%$ di antaranya merupakan asam lemak jenuh. Komposisi asam lemak pada minyak kelapa dapat dilihat pada Tabel 1

Tabel 1. Komposisi Asam Lemak Minyak Kelapa yang Digunakan

\begin{tabular}{|l|c|r|}
\hline \multicolumn{1}{|c|}{$\begin{array}{c}\text { Jenis Asam } \\
\text { Lemak }\end{array}$} & $\begin{array}{c}\text { Nomor } \\
\text { Lipid }\end{array}$ & $\begin{array}{c}\text { Kandungan } \\
(\mathbf{\%})\end{array}$ \\
\hline Asam Kaproat & C6-0 & 0,3573 \\
\hline Asam Kaprilat & C8-0 & 6,1101 \\
\hline Asam Kaprat & C10-0 & 4,7605 \\
\hline Asam Laurat & C12-0 & 47,5994 \\
\hline Asam Miristat & C14-0 & 20,7215 \\
\hline Asam Palmitat & $\mathrm{C} 16-0$ & 9,4841 \\
\hline Asam Stearat & $\mathrm{C} 18-0$ & 2,9551 \\
\hline Asam Oleat & $\mathrm{C} 18-1$ & 6,6128 \\
\hline Asam Linoleat & $\mathrm{C} 18-2$ & 1,3064 \\
\hline Asam Arakidat & $\mathrm{C} 20: 0$ & 0,0664 \\
\hline
\end{tabular}

\section{Kaolin}

Kaolin sering digunakan untuk menyebut mineral lempung putih yang mempunyai komposisi terbesar berupa kaolinit $\left(\mathrm{Al}_{2} \mathrm{O}_{3} \cdot 2 \mathrm{SiO}_{2} \cdot 2 \mathrm{H}_{2} \mathrm{O}\right)$. Mineral kaolin dapat terjadi melalui proses pelapukan dan proses hidrotermal alterasi pada batuan beku felspartik dan mika[3].

Semua bahan anorganik padatan dari tanah memiliki daya serap terhadap hampir semua partikel, molekul, dan ion-ion yang masuk ke dalam struktur tanah melalui pelarutan dengan air, bahkan lebih lanjut dapat mengamobilisasi semua bentuk sel mikroorganisme. Sifat tersebut berasal dari kerangka struktur umum senyawa-senyawa silikat dan aluminosilikat yang bermuatan, mampu berinteraksi melalui mekanisme ionik maupun kepolaran [5].

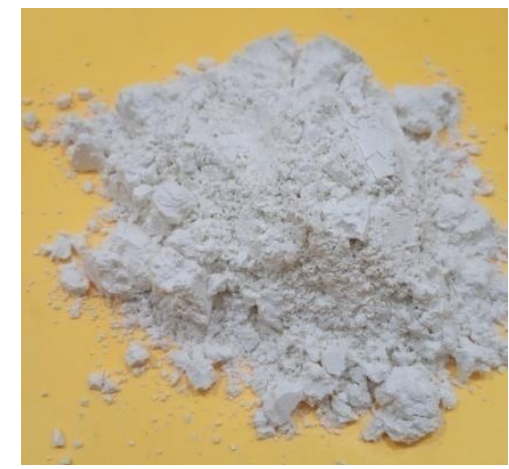

Gambar 1. Kaolin

Sabun

Sabun merupakan hasil dari proses saponifikasi. Saponifikasi adalah proses penyabunan yang mereaksikan suatu lemak atau gliserida dengan basa. Menurut SNI 06-3532-2016sabun mandi didefinisikan sebagai senyawa Natrium dengan asam lemak yang digunakan sebagai pembersih tubuh, berbentuk padat, berbusa, dengan atau penambahan lain serta tidak menyebabkan iritasi pada kulit[7].

\section{Polimerase Chain Reaction (PCR)}

Polymerase Chain Reaction(PCR) merupakan suatu teknik atau metode perbanyakan (replikasi) DNA secara enzimatik tanpa menggunakan organisme. Dengan teknik ini, DNA dapat dihasilkan dalam jumlah besar dengan waktu relatif singkat sehingga memudahkan berbagai teknik lain yang menggunakan DNA. Penerapan PCR banyak dilakukan di bidang biokimia dan biologi molekular karena relatif murah dan hanya memerlukan jumlah sampel yang kecil [8].

\section{Metodologi Penelitian}

Minyak kelapa, $\mathrm{NaOH}$, aquadest dan kaolin digunakan sebagai bahan utama pembuatan sabun. Bahan lain seperti etanol, phenolphthaleindan asam klorida sebagai bahan penganalisa sampel sabun yang diproduksi.

Reaksi penyabunan dilangsungkan dalam beakerglass pada suhu yang bervariasi $\left(50^{\circ} \mathrm{C}, 60^{\circ} \mathrm{C}\right.$, $70^{\circ} \mathrm{C}$ dan $80^{\circ} \mathrm{C}$ ) dan konsistensi kaolin yang berbeda $10 \%, 12.5 \%, 15 \%, 17.5 \%, 20 \%)$. Reaksi berlangsung 
selama 10 menit dengan perbandingan jumlah minyak kelapa, $\mathrm{NaOH} 35 \%$ sebanyak 7:3 (b:v) dan kecepatan pengadukan yang konstan $250 \mathrm{rpm}$.

Adapun analisis yang dilakukan pada setiap sampeldalam penelitian ini berdasarkan Standar Nasional Indonesia (SNI06-3532-2016) berupa:

1. Analisis kadar air

2. Analisis kadar alkali bebas

3. Analisis derajat keasaman $(\mathrm{pH})$

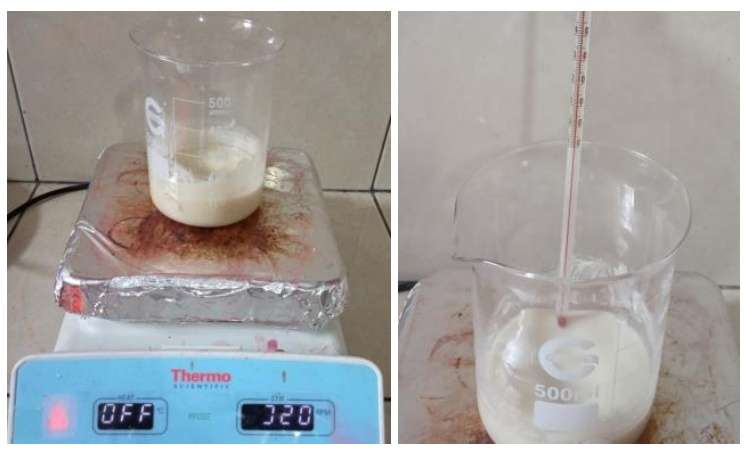

Gambar 2. Proses Pembuatan Sabun

\section{Hasil}

\section{Analisa Mutu SNI Sabun Padat}

Berdasarkan analisa, kandungan air didalam sabun meningkat seiring dengan meningkatnya konsistensi kaolin dan temperatur. Dlapa et al (2004) menyebutkan dari hasil penelitiannya bahwa gugus hidroksil kaolin memiliki kerapatan yang tinggi, sehingga kaolin memiliki kemampuan mengikat air dengan baik digandingkan dengan tanah liat yang lain[9]. Penelitian sebelumnya tersebut mendukung kesesuain hasil yang didapat pada penelitian ini.

Hasil analisa asam lemak bebas (ALB) pada Tabel 1 menunjukkan kadar ALB sabun berada pada 0.15 - $0.6 \%$. ALB paling tinggi ditemukan pada konsistensi kaolin $10 \%$ pada $50^{\circ} \mathrm{C}$ dan ALB terndah terdapat pada sabun dengan konsistensi kaolin $20 \%$ pada suhu $80^{\circ} \mathrm{C}$. Kadarasam lemak sabunsemakinmenurunseiringdengannaiknyasuhurea ksi[10]. Kaolin mengandung $\mathrm{SiO}_{2}$, struktursilicaoksida yang tetrahedral dan membentukronggasehinggabiasa

digunakansebagaiadsorbenuntukmenurunkanasam lemak bebas[11]. Silika mampu mengadsorbsi asam lemak bebas sebesar $140 \mathrm{~g}$ FFA/ $100 \mathrm{~g}$ sampel pada pemurnian biodiesel berbasis adsorbsi[12]. Penelitian terdahulu mendukung hasil yang didapatkan pada penelitian ini, yaitu kadar asam lemak bebas menurun seiring dengan penambahan konsistensi kaolin dan meningkatnya suhu reaksi.

Data hasil penelitian ini ditampilkan pada Tabel 4. Semua data yang diambil mengacu pada standart SNI06-3532-2016 meliputi kandungan air sabun, asam lemak bebas (ALB) serta alkali bebas.
Tabel 1. Analisa Sabun Padat berdasarkan SNI 2016

\begin{tabular}{|c|c|c|c|c|}
\hline Variasi & Suhu & $\begin{array}{c}\text { Kandungan } \\
\text { air }\end{array}$ & ALB & $\begin{array}{l}\text { Alkali } \\
\text { Bebas }\end{array}$ \\
\hline SNI & $\left({ }^{\circ} \mathrm{C}\right)$ & $<15 \%$ & $<2,5 \%$ & $<0,1 \%$ \\
\hline \multirow{4}{*}{$\begin{array}{c}\text { kaolin } \\
10 \%\end{array}$} & 50 & 3,58 & 1,03 & - \\
\hline & 60 & 1,69 & 0,94 & - \\
\hline & 70 & 3,30 & 0,90 & - \\
\hline & 80 & 4,65 & 0,62 & - \\
\hline \multirow{4}{*}{$\begin{array}{l}\text { kaolin } \\
12,5 \%\end{array}$} & 50 & 3,96 & 0,98 & - \\
\hline & 60 & 2,80 & 0,92 & - \\
\hline & 70 & 3,56 & 0,90 & - \\
\hline & 80 & 5,32 & 0,57 & - \\
\hline \multirow{4}{*}{$\begin{array}{c}\text { kaolin } \\
15 \%\end{array}$} & 50 & 3,22 & 0,90 & - \\
\hline & 60 & 3,39 & 0,86 & - \\
\hline & 70 & 3,92 & 0,82 & - \\
\hline & 80 & 6,02 & 0,53 & - \\
\hline \multirow{4}{*}{$\begin{array}{l}\text { kaolin } \\
17,5 \%\end{array}$} & 50 & 3,63 & 0,70 & - \\
\hline & 60 & 3,94 & 0,82 & - \\
\hline & 70 & 3,81 & 0,74 & - \\
\hline & 80 & 6,10 & 0,53 & - \\
\hline \multirow{4}{*}{$\begin{array}{c}\text { kaolin } \\
20 \%\end{array}$} & 50 & 4,15 & 0,62 & - \\
\hline & 60 & 4,39 & 0,29 & - \\
\hline & 70 & 3,79 & 0,70 & - \\
\hline & 80 & 6,11 & 0,47 & - \\
\hline
\end{tabular}

Dalam penelitian ini dengan penambahan konsistensi Kaolin tidak meningkatkankadar alkali bebas (kadar alkali bebas 0\%) dimana tidak terjadi perubahan warna larutan sabun menjadi merah muda setelah penambahan indikator phenolphtalein.

\section{Uji Penghilangan DNA}

Gambar 1 menunjukkan hasil uji PCR pada DNA, sampel DNA Babi dilakukan dengan metode swab menggunakan Sterryl Cotton Bud lalu dilakukan metode lanjutan dan diuji menggunakan PCR. Metode ini digunakan untuk melihat DNA yang tersisa pada tangan manusia setelah dicuci menggunakan air mengalir, sabun X, dan juga sabun samak.

Pada Gambar 3. terdapat berbagai macam pencucian, pencucian dilakukan dengan air bersih mengalir dan sabun konvensional. Sisa DNA tidak dapat dihilangkan hanya menggunakan bilasan air mengalir saja, ini ditunjukkan dengan masih adanya pita DNA pada Gambar 3 (A1, A2, A3). Proses pembersihan oleh air merupakan proses pelarutan zat yang dianggap sebagai pengotor/polutan. Zat-zat yang tergolong elektrolit dan zat-zat lain yang polar dapat dihilangkan melalui proses pelarutan oleh air[4]. Air tidak dapat membersihkan DNA dikarenakan air tidak mampu mengisolasi DNA dari media. Pada Gambar 3 
ditampilkan hasil pencucian DNA dengan air dan Gambar 4 menampilkan hasil pencucian DNA dengan Sabun X.

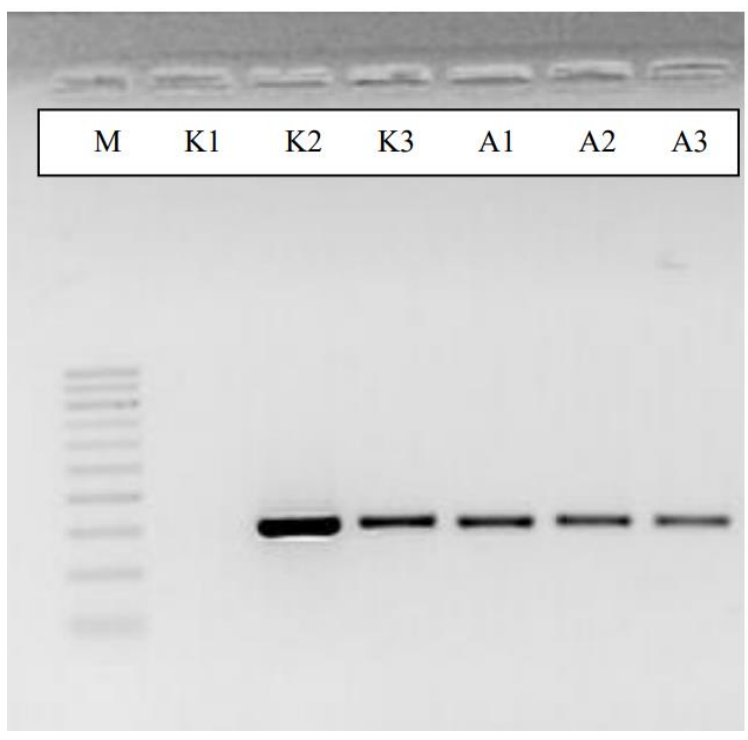

Gambar 3. Pencucian DNA dengan Air

Keterangan Gambar 3:

M : Marka

K1 : Kontrol Negatif (tidak ada DNA Babi)

K2 : Kontrol Positif (Terdapat DNA Babi)

K3 : Kontrol Positif (DNA Babi di tangan manusia)

A1 : Pencucian dengan air pertama

A2 : Pencucian dengan air ke-2

A3 : Pencucian dengan air ke-3

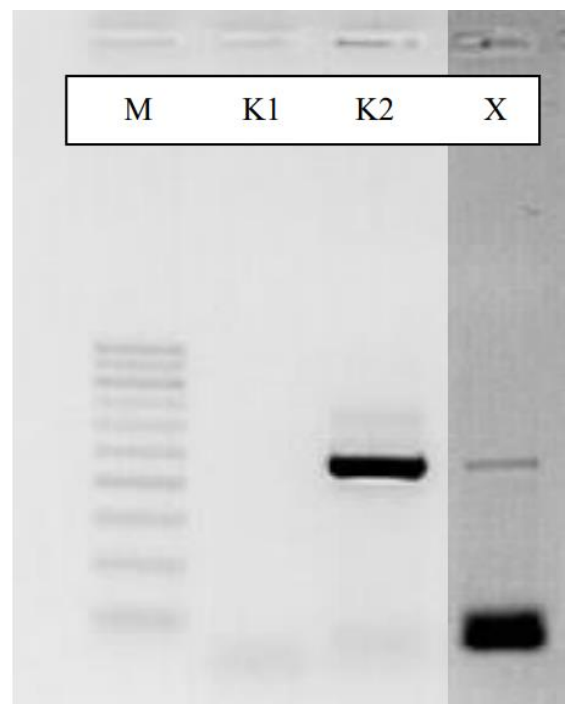

Gambar 4. Pencucian DNA dengan Sabun X

Keterangan Gambar 3:

M : Marka

K1 : Kontrol Negatif (tidak ada DNA Babi)

K2 : Kontrol Positif (DNA Babi di tangan manusia)

X1 : Pencucian dengan Sabun X

Pencucian menggunakan sabun konvensional (tanpa tanah) tidak mampu menghilangkan DNA Babi dikarenakan sabun hanya mengurangi tegangan permukaan dan menghilangkan lemak dan kotoran [11]tetapi tidak mampu menghilangkan DNA Babi.

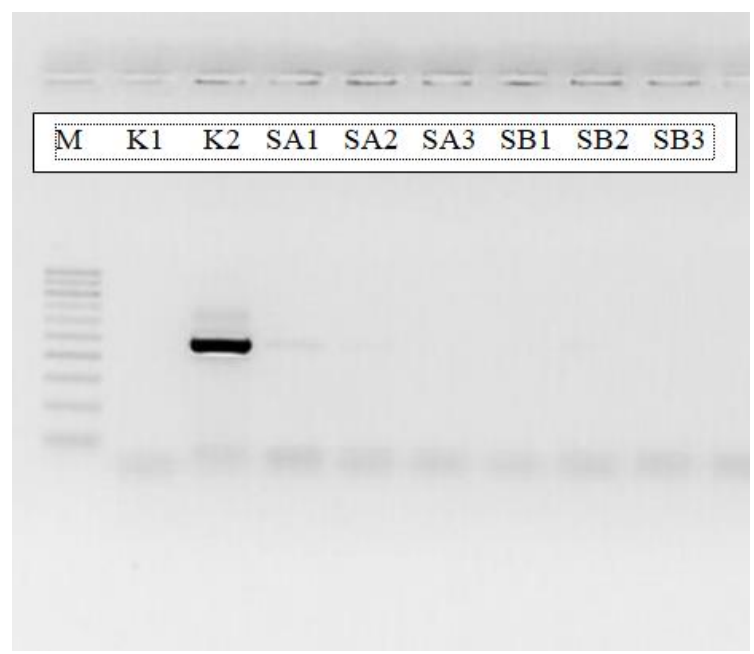

Gambar 5. Pencucian DNA dengan Sabun Samak

Keterangan Gambar 5:

M : Marka

K1 : Kontrol Negatif (tidak ada DNA Babi)

K2 : Kontrol Positif (DNA Babi di tangan manusia)

$\mathrm{Sa} 1$ : pencucian dengan sabun $\left(15 \%, 50^{\circ} \mathrm{C}\right) \mathrm{ke}-1$

$\mathrm{Sa} 2$ : pencucian dengan sabun $\left(15 \%, 50^{\circ} \mathrm{C}\right) \mathrm{ke}-2$

$\mathrm{Sa} 3$ : pencucian dengan sabun $\left(15 \%, 50^{\circ} \mathrm{C}\right) \mathrm{ke}-3$

$\mathrm{Sb} 1$ : pencucian dengan sabun $\left(17,5 \%, 60^{\circ} \mathrm{C}\right) \mathrm{ke}-1$

$\mathrm{Sb} 2$ : pencucian dengan sabun $\left(17,5 \%, 60^{\circ} \mathrm{C}\right) \mathrm{ke}-2$

$\mathrm{Sb} 3$ : pencucian dengan sabun $\left(17,5 \%, 60^{\circ} \mathrm{C}\right) \mathrm{ke}-3$

Sabun Samak dengan variasi konsistensi kaolin dan bentonit mampu menghilangkan DNA Babi yang dioleskan pada tangan peneliti dengan satu kali pencucian. Hal ini dibuktikan dengan tidak adanya pita DNA yang terdeteksi pada uji PCR setelah dilakukan perlakuan pencucian sabun samak pada sampel tangan yang telah dioleskan sampelDNA.

Dapat dilihat pada Gambar 5. DNA Babi hilang setelah dibersihkan menggunakan sabun samak (sabun berpengisi kaolin/bentonit). Tanah yang dicampur air akan menghasilkan suspensi tanah yang makin memperkuat sifat adsorbansi karena permukaannya semakin luas[5]. Komponen tanah liat memiliki partikel yang mampu menukar kation [13]. Kaolin sebagai pengisi sabun samak mengandung 46.54\% $\mathrm{SiO}_{2}, 39.50 \% \mathrm{Al}_{2} \mathrm{O}_{3}$ [14]. Kandungan silika pada kaolin dan Fbentonit membantu mengadsorbsi DNA.Prinsip dari pengikatan silika dengan DNA adalah berdasarkan dari tingginya ikatan negatif di struktur DNA terhadap muatan positif pada ikatan silika. Natrium yang berikatan dengan silika pada sabun berperan sebagai jembatan kation yang menarik oksigen bermuatan negatif pada gugus posfat di asam nukleotida DNA. Pemurnian molekul DNA dapat terjadi pada kadar ion yang rendah $(\mathrm{pH} \geq 7)$ kemudian dengan menggunakan buffer atau air suling [15]. 
Kemampuan sabun samak menghilangkan DNA dengan cara mengikis partikel lemak yang terdapat pada massa pembawa DNA, lalu DNA diikat oleh silika yang dikandung oleh Kaolin untuk kemudian hilang terbawa oleh air setelah dibilas.

\section{Kesimpulan}

Sabun padat kaolin yang dihasilkan pada setiap variasi memenuhi standar SNI.Sabun padat terbaik adalah sabun samak kaolin $15 \%\left(50^{\circ} \mathrm{C}\right), 17,5 \%$ $\left(60^{\circ} \mathrm{C}\right)$, berdasarkanperbandingan sifat kekerasan sabun terhadap sabun konvensional.Sabun samak berpengisi kaolin $15 \%\left(50^{\circ} \mathrm{C}\right), 17,5 \%\left(60^{\circ} \mathrm{C}\right)$, mampu menghilangkan najis mughallazah.

\section{Ucapan Terima Kasih}

Ucapan terimakasih ditujukan kepada Lembaga Penelitian dan Pengabdian Masyarakat Universitas Sumatera Utara untuk pendanaan penelitian ini pada Penelitian Terapan TALENTA 2019.

\section{Daftar Pustaka}

[1] S. Chairunnisyah, "Peran Majelis Ulama Indonesia Dalam Menerbitkan Sertifikat Halal Pada Produk Makanan Dan Kosmetika," EduTech J. Ilmu Pendidik. dan Ilmu Sos., vol. 3, no. 2, pp. 64-75, 2017.

[2] P. A. A. Putra, "Kedudukan Sertifikasi Halal Dalam Sistem Hukum Nasional Sebagai Upaya Perlindungan Konsumen Dalam Hukum Islam," J. Ekon. dan Keuang. Syariah, vol. 1, no. 1, pp. 150-165, 2017.

[3] S. T. M. Tuan and R. Ahmad, "Aplikasi alIstihalah dalam Industri Halal Semasa Menurut Perspektif Maqasid al-Shariah," Int. J. Humanit. Technol. Civiliz., vol. 2, no. 1, pp. 1-9, 2017.

[4] A. A. Taha, A. M. Ahmed, H. H. Abdel Rahman, F. M. Abouzeid, and M. O. Abdel Maksoud, "Removal of nickel ions by adsorption on nano-bentonite: Equilibrium, kinetics, and thermodynamics," J. Dispers. Sci. Technol., vol. 38, no. 5, pp. 757-767, 2017.

[5] N. Kassim, P. Hashim, D. M. Hashim, and H. Jol, "New Approach of Samak Clay Usage for Halal Industry Requirement," Procedia - Soc. Behav. Sci., vol. 121, no. September 2012, pp. 186-192, 2014.

[6] A. A. Aja and G. J. Randy, "Physical Properties of Kaolin Used in Soap Production in Nigeria Physical Properties of Kaolin Used In Soap Production In Nigeria," Int. J. Eng. Sci., vol. 2, no. 10, pp. 10-15, 2013.

[7] Y. Sukawaty, H. Warnida, and A. V. Artha, "Formulasi Sediaan Sabun Mandi Padat Ekstrak Etanol Umbi Bawang Tiwai (Eleutherine bulbosa (Mill.) Urb.)," Media Farm., vol. 13, no. 1, pp. 14-22, 2016.

[8] E. Hasibuan, "Peranan Teknik Polymerase
Chain Reaction (Pcr) Terhadap Perkembangan Ilmu Pengetahuan," Karya Tulis Ilmiah, Universitas Sumatera Utara, Medan, 2015.

[9] P. Dlapa, S. H. Doerr, L. Lichner, M. Šír, and M. Tesař, "Effect of kaolinite and $\mathrm{Ca}$ montmorillonite on the alleviation of soil water repellency," Plant, Soil Environ., vol. 50, no. 8, pp. 358-363, 2004.

[10] L. Sukesi, A. Sidabutar, and C. Sitorus, "C, waktu pengadukan 60 menit, 90 menit, 120 menit. Respon yang diamati adalah densitas, Keasaman $(\mathrm{pH})$, bilangan penyabunan dan alkali bebas. Hasil yang terbaik diperoleh pada suhu 80," J. Tek. Kim., vol. 6, no. 3, pp. 8-13, 2017.

[11] A. I. Suryani, "Penurunan Asam Lemak Bebas Dan Transesterfikasi Minyak Jelantah Menggunakan Kopelarut Metil Tersier Butil Eter (Mtbe)," Skripsi, Universitas Sebelas Maret, Surakarta, 2009.

[12] D. L. Manuale, V. M. Mazzieri, G. Torres, C. R. Vera, and J. C. Yori, "Non-catalytic biodiesel process with adsorption-based refining," Fuel, vol. 90, no. 3, pp. 1188-1196, 2011.

[13] J. P. Nirschl and R. A. Gloss, "Detergent Compositions Containing Asmectite-Type Clay Softening Agent," United States Patent, Ohio, 1975.

[14] Sunardi, Utami Irawati, and T. Wianto, "Karakterisasi Kaolin Lokal Kalimantan Selatan Hasil Kalsinasi," J. Fis. Flux, vol. Vol 8, pp. 59-65, 2011.

[15] S. C. Tan and B. C. Yiap, "DNA, RNA, and protein extraction: The past and the present," $J$. Biomed. Biotechnol., vol. 2009, 2009. 